\begin{tabular}{lll} 
KULTURA & $\begin{array}{l}\text { POLSKA A KADEMIA NAUK } \\
\text { KOMITET SOCJOLOGII }\end{array}$ & ISSN 0023-5172 \\
i & $\begin{array}{l}\text { INSTYTUT STUDIÓW POLITYCZNYCH } \\
\text { SPOLECLENSTWO nr } 3 \quad \text { AUTOETNOGRAFIA }\end{array}$ & \\
\hline
\end{tabular}

PRZEMYSEAW RURA

Uniwersytet im. Adama Mickiewicza w Poznaniu

Instytut Socjologii

\title{
DOŚWIADCZENIA ZMYSŁOWE W ŻYCIU CODZIENNYM: AUTOETNOGRAFIA WIELOZMYSŁOWA
}

\section{ZMYSŁY I ŻYCIE CODZIENNE}

W socjologii - a także szerzej: w naukach społecznych i humanistycznych - można zauważyć swoisty zwrot ku codzienności. Na początku XXI wieku powstało wiele prac poświęconych tej tematyce (zob. Sulima 2000; Bogunia-Borowska, Sztompka 2008; Bogunia Borowska 2009a; Drozdowski 2012; Rogowski, Skrobacki, Mroczkowska 2012; Maślanka, Strzyczkowski 2012), choć nie jest ona nowa w naukach społecznych i humanistycznych - wystarczy wspomnieć prace Simmla, Eliasa czy Kaufmanna, a na gruncie polskim znakomity zespół badawczy z Instytutu Filozofii i Socjologii PAN pod kierownictwem Andrzeja Sicińskiego. Rafał Drozdowski (2012) wskazuje na dziewięć przyczyn „mody” na socjologię codzienności, wśród których najważniejsze są, moim zdaniem, kryzys intersubiektywności, przekonanie o coraz większym ukryciu makrostrukturalnych mechanizmów rządzących porządkiem społecznym, a także o tym, że „kołem zamachowym najważniejszych zmian społecznych jest oparta na refleksyjności autonomia oraz podmiotowość rozmaitych zbiorowych (i zwłaszcza indywidualnych) aktorów społecznych" (Drozdowski 2012, s. 6). Skupienie się na codzienności oraz mikropraktykach może być więc traktowane jako remedium na wiele socjologicznych bolączek czy przeoczeń. Zwrot ku codziennym praktykom pozwala bowiem nadrobić wcześniejszy brak zainteresowania i wyczerpujących socjologicznych opracowań dotyczących na przykład 
pracy domowej kobiet (Drozdowski 2012, s. 7). Jednocześnie jest to podejście „bezpieczne” w czasach, w których niemal niemożliwe staje się przewidywanie zmian strukturalnych, systemowych czy funkcjonalnych (Bogunia Borowska 2012b, s. 12). W odpowiedzi na pytanie o to, co da się wyjaśnić poprzez badanie codzienności, można wyróżnić zatem trzy modele eksplanacyjne. Po pierwsze, dzięki analizom praktyk codziennych możemy dotrzeć do ogólniejszych mechanizmów w skali makro. Po drugie, mikropraktyki mogą stanowić dobry wskaźnik - zapowiedź zmian strukturalnych. Po trzecie, nawet najbardziej banalne mikropraktyki mogą być traktowane jako część pewnego wycinka rzeczywistości społecznej, choć nie odsyłają do niczego innego, lecz tylko do codzienności (Drozdowski 2012, s. 10). W każdym z tych przypadków zejście w socjologicznych analizach do poziomu mikro i przyjrzenie się wcześniej banalizowanym aspektom funkcjonowania rzeczywistości społecznej wydaje się nie tylko ciekawe, ale również obiecujące poznawczo. Opisywane zazwyczaj przez literaturę przemiany związane z ludzką intymnością czy emocjami, materialnością oraz ciałem czy cielesnością zajmują główne miejsce w polu zainteresowania badaczy socjologii codzienności (Sztompka 2008; Bogunia-Borowska 2012b, s. 7).

Takie podejście teoretyczne przynosi jednocześnie obietnicę rozwiązań metodologicznych, dzięki którym można zbudować pomost pomiędzy socjologią, etnologią, antropologią kulturową, a także geografią społeczną czy ekonomią i psychologią (Drozdowski 2012, s. 5). Analizy codzienności wpisują się głównie w „miękką” socjologię, sięgającą do tradycji socjologii humanistycznej oraz jakościowych metod i technik badawczych. Można wśród nich wymienić metodę pamiętnikarską (Kurczewski 2009), wywiady przeprowadzane przez internet (Grzeszczyk 2009), analizy wizualne (Olechnicki 2009; Bendiner-Viani 2011). Z uwagi na przedmiot zainteresowania - codzienność, mikropraktyki, cielesność - obiecującą metodą badawczą wydaje się również autoetnografia.

\section{O AUTOETNOGRAFII}

W ostatnich dwóch lub trzech dziesięcioleciach można było zaobserwować rosnące zainteresowanie autoetnografią. Według Leona Andersona fakt ten wiąże się z kilkoma „zwrotami” w naukach społecznych oraz humanistycznych: „[...] ze zwrotem $\mathrm{w}$ stronę zmąconych gatunków pisarstwa (blurred genres of writing), ze wzmożoną autorefleksyjnością badań etnograficznych, ze zwiększonym zainteresowaniem emocjami $w$ naukach społecznych czy wreszcie z postmodernistycznym sceptycyzmem wobec możliwości generalizacji twierdzeń naukowych (knowledge claims)" (Anderson 2014 [2006], s. 145). Autoetnografia zyskuje popularność $w$ wielu dyscyplinach naukowych, takich jak socjologia, antropologia czy nauka o komunikacji, a także w wielu innych obszarach badań społecznych (Kacperczyk 2014, s. 33). Mimo to trudno znaleźć precyzyjną 
definicję tej metody - na przykład Carolyn Ellis i Arthur P. Bochner (2000) wymieniają aż czterdzieści nazw, które różni autorzy stosują w opisach podejścia autoetnograficznego. Termin ,autoetnografia”, jako określenie spontanicznych opowieści autochtonów, został wprowadzony do pola nauki przez antropologa Karla Heidera pod koniec lat siedemdziesiątych XX wieku. Następnie użył go David Hayano (1979), zwracając uwagę na pozytywną rolę badacza w badanej społeczności. Jednak dopiero w pracach przywołanych już Carolyn Ellis i Arthura P. Bochnera termin ten został doprecyzowany (zob. Bielecka-Prus 2014, s. 78). Zadania systematyzacji podejść podjęła się również Anna Kacperczyk i wskazała, że rozumieć można autoetnografię jako:

(1) „bazujący na procesie introspekcji akt autonarracji”, gdy na pierwszym miejscu nie stoi forma utrwalenia narracji, ale sama czynność - uruchomiony przez podmiot proces umysłowy, czynność autoanalityczna i autorefleksyjna, dzięki której lepiej rozumie się świat;

(2) „efekt i produkt” procesów autoanalitycznych i autorefleksyjnych (esej, tekst, performance);

(3) technika pozyskiwania danych;

(4) całościowa strategia badawcza, w której badacz uczestniczący w jakimś procesie społecznym dokonuje w dłuższym okresie celowej i planowanej autoobserwacji;

(5) „nowatorski wzorzec uprawiania nauki w polu nauk społecznych”; przy takim podejściu autoetnografia traktowana jest jako sposób wytwarzania wiedzy ze szczególnym naciskiem na relację, jaka powstaje między narratorem (badaczem) a jego odbiorcą - słuchaczem, czytelnikiem czy też widzem (Kacperczyk 2014, s. 37-39).

Niezależnie od dyskusji dotyczącej definicji pojęcia oraz jego zakresu znaczeniowego warto zarysować założenia teoretyczne i metodologiczne, a także ogólniejsze „okoliczności naukowe”, bez których autoetnografia nie zyskałaby takiej popularności, jaką cieszy się obecnie.

Po pierwsze, badacze i teoretycy sięgający po autoetnografię są reprezentantami podejścia jakościowego w naukach społecznych oraz humanistycznych. Takie nastawienie teoretyczno-metodologiczne ma wiele punktów wspólnych $z$ antypozytywizmem. Oznacza jednak nie tyle zanegowanie paradygmatu pozytywistycznego, ile raczej uzupełnienie go „metodami humanistycznymi” (zob. Mokrzycki 1971, s. 37). Zaburzone zostaje tym samym pozytywistyczne rozróżnienie na podmiot (poznający) oraz przedmiot (poznawany). To odrzucenie paradygmatu pozytywistycznego jako jedynie obowiązującego w naukach społecznych i humanistycznych niesie ze sobą z jednej strony umocnienie przekonania o sile i potencjale badań jakościowych, a $z$ drugiej - przeświadczenie o tym, że badanie złożoności zjawisk społecznych wymaga uwzględnienia jednostkowych doświadczeń uczestników życia zbiorowego. Próby dotarcia do tego, jak świat społeczny jawi się w świadomości badanego, stanowią zatem jeden $z$ filarów opisywanej postawy teoretyczno-metodologicznej. Badania prowadzone 
w tym nurcie uwzględniają „współczynnik humanistyczny” Znanieckiego jest to jedna $z$ podstawowych zasad socjologii humanistycznej.

Po drugie, szczególny wpływ na popularność autoetnografii ma zwrot postmodernistyczny w naukach społecznych i humanistycznych wraz z jego poststrukturalistycznymi implikacjami (Dziamski 2001, s. 43). Postmodernistyczny sceptycyzm co do schematów wytwarzania wiedzy, o którym wspomina Anderson (2014), polega na dystansowaniu się wobec wszelkich „wielkich narracji” i uwzględnianiu narracji mniejszych, jednostkowych (Kacperczyk 2014, s. 36). Dotyczy to sposobów nie tylko postrzegania świata, ale również jego badania. Metody jakościowe, uwzględnianie pojedynczych narracji aktorów społecznych, a także dekonstrukcja Derridy stanowią podstawy opisywanego podejścia. Koncepcja autoetnografii syntetyzuje postmodernistyczną etnografię, w której zostaje zakwestionowana „realistyczna konwencja” i obiektywność obserwatora, a także postmodernistyczną formę autobiografii, w której kwestionowana jest koncepcja siebie jako jednostki spójnej tożsamościowo (Reed-Danahay 1997, s. 4).

Po trzecie, u podwalin autoetnografii znajduje się założenie o refleksyjności aktorów społecznych jako niemal konstytutywnej cesze współczesnego społeczeństwa. Od połowy XX wieku „refleksyjność” zyskiwała coraz większe znaczenie w dyskursie nauk społecznych i humanistycznych, aż stała się jednym $z$ terminów kluczowych (Hałas 2011, s. 192). Wiele uwagi poświęcił temu zagadnieniu między innymi Anthony Giddens (2007, s. 120), który wprowadził pojęcie refleksyjnego monitorowania działań jednostki. Oparł się na założeniu o występowaniu w życiu codziennym ludzi i w praktykach tej sfery dwu form świadomości: praktycznej oraz dyskursywnej. Pierwsza to świadomość tego, co wokół danego aktora społecznego się dzieje, i umiejętność dostosowania się do tego kontekstu, innymi słowy - refleksyjne podjęcie działania, które wynika $z$ definicji sytuacji oraz do niej przystaje. Druga forma świadomości, zdaniem Giddensa (2007, s. 121), polega na tym, że aktor społeczny potrafi podjęte przez siebie działania uzasadnić w szerszym kontekście kulturowym - jest to więc forma racjonalizacji własnego działania. Teoria brytyjskiego socjologa wydaje się ważna dla autoetnografów, ponieważ prowadzenie badań wymaga od nich nie tylko wnikliwej oceny sytuacji oraz umiejętności zaadaptowania do niej swoich działań, ale również umiejętności urefleksyjnienia i opisania tych działań w kontekście zbioru reguł, norm i wartości badanej społeczności.

Opisane założenia odnoszą się nie tylko do badanych, ale również do badacza, czego konsekwencją jest jego „upodmiotowienie” w procesie zbierania danych oraz ich późniejszej analizy. Wiąże się to z zakwestionowaniem możliwości obiektywnego prowadzenia badań. Zakłada się bowiem, że naukę uprawiają nie abstrakcyjne postaci znajdujące się „poza” badanym społeczeństwem, lecz zakorzenione w nim jednostki, których doświadczenie i biografia wpływają na badanie, a także na odwrót - badanie wpływa na ich doświadczenie i biografię (Loftland i in. 2009; Kafar 2011). Stanowi to z kolei argument za postu- 
latem Roya Wagnera (2003, s. 60), by odrzucić klasyczną formę obiektywności (absolutnej) na rzecz tego, co określa on mianem „względnej obiektywności", czyli brać pod uwagę własne kulturowe ograniczenia. Namysł nad tym, że badacz jest obarczony pewnym bagażem doświadczeń wynoszonych z własnej kultury, jest kluczowy dla zrozumienia zarówno innej, jak i własnej kultury. Samo doświadczenie kulturowe staje się jednym z elementów pracy badawczej, a gdy — jak zauważa Radosław Kossakowski $(2014$, s. 98) — „[...] eksploruje się własną kulturę (również taką, która stała się «własna» $\mathrm{z}$ różnych powodów — konwersji, zmiany statusu, awansu itd.), element autoanalizy jest nie tylko metodologicznie konieczny, ale etycznie uzasadniony oraz cenny dla kształtowania ludzkiej refleksyjności". Zwraca się też uwagę na fakt, że szczególną rolę w procesie badawczym odgrywa sam badacz: ,jego autorefleksyjność stanowi nie tylko jeden $z$ istotnych sposobów intersubiektywnego sprawdzania danych, ale czasem jedyny sposób docierania do obszarów, które w tradycyjnych badaniach nie byłyby dostępne" (Kacperczyk 2012, s. 37). Refleksyjność badacza - zdaniem Anny Kacperczyk - jest aktem samoreferencji, analizy przyczyn własnych działań badawczych i osadzania ich w szerszym kontekście społecznym, kulturowym czy politycznym. Świadomy badacz analizuje to, co wnosi do procesu badawczego, a także to, jak się zmienia ten proces pod wpływem jego obecności $\mathrm{w}$ analizowanym polu.

Chociaż nie ma zgody co do definicji autoetnografii, można wskazać jej dwa główne typy szeroko omówione w literaturze: autoetnografię ewokatywną (evocative autoethnography) (Ellis 1995, 2004; Ellis Bochner 2000; Denzin 2006) oraz autoetnografię analityczną (analytic autoethnography) (Anderson 2014). Pierwsza akcentuje szczególną relację między badaczem i badanym, u jej podstaw najczęściej leżą silne doświadczenia emocjonalne. Głównym celem takiej aueotnografii jest dotarcie do ludzi i wywołanie określonego efektu, który ma im pomóc w zrozumieniu siebie i otaczającego świata (zob. Kacperczyk 2012; Ellis 1995). Druga nawiązuje do tradycyjnej etnografii, wysuwa jednak postulat wzbogacenia jej o indywidualne odczucia oraz refleksje badacza. Narracja uwzględnia osobiste odniesienia badacza, którego obecność jest zaznaczona również na poziomie tekstu. W toku pracy korzysta on z różnych technik (np. wywiadu swobodnego, notatek terenowych), by krytycznie ująć własne doświadczenie danej kultury, co ma pozwolić na odniesienie wniosków do szerszych kontekstów społeczno-kulturowych (zob. Anderson 2014).

\section{AUTOETNOGRAFIA JAKO SPOSÓB BADANIA WIELOZMYSŁOWOŚCI W ŻYCIU CODZIENNYM}

Proponowana przeze mnie autoetnografia wielozmysłowa stanowi swoistą wypadkową przedstawionych podejść - innymi słowy, łączy cechy autoetnografii analitycznej oraz ewokatywnej (choć skłania się ku tej pierwszej). Po 
pierwsze, spełnia wszystkie pięć kluczowych, według Andersona, warunków autoetnografii analitycznej, czyli: „(1) pełne uczestnictwo badacza w badanym środowisku (complete member researcher - CMR), (2) refleksyjność analityczna, (3) obecność własnego Ja badacza w narracji, (4) dialog z innymi informatorami niż Ja badacza i (5) zaangażowanie w analizę teoretyczną" (Anderson 2014, s. 149). Po drugie zaś, co charakterystyczne dla etnografii ewokatywnej, pogłębionej analizie są poddawane własne doświadczenia, na podstawie których powstaje refleksyjna autonarracja. Efektem zbieranych w tym nurcie informacji, oprócz raportu z badań czy artykułu, może być również, tak jak proponują Carolyn Ellis i Arthur Bochner (2000, s. 739): „tekst pisany, występ, film czy esej fotograficzny".

Moja propozycja autoetnografii nawiązuje do etnografii wielozmysłowej (sensory ethnography) zaproponowanej przez Sarah Pink (2009, s. 1). Jej zdaniem jest to taki sposób myślenia i uprawiania etnografii, w którym punktem wyjścia staje się wielozmysłowe doświadczenie, postrzeganie oraz oparte na tym doświadczeniu wiedza i praktyka. Ważnym elementem jest więc bezpośredni i relatywnie długotrwały kontakt $z$ badanymi, uwzględniający kontekst ich życia codziennego, co umożliwia dotarcie do poziomu praktyk oraz wiedzy wynikającej z ich doświadczenia. Taki rodzaj etnografii uważany jest raczej za rozwijające się pole praktyk etnograficznych niż ich pojedynczy, ściśle określony model. Etnografia wielozmysłowa zakłada względną dowolność w korzystaniu z technik docierania do wiedzy oraz praktyk badanych. Jednak — jak zauważa Pink proponowane podejście powinno bazować na obserwacji uczestniczącej (pozwalającej obserwować oraz współodczuwać) oraz wywiadach (dzięki którym możliwa jest eksploracja zaobserwowanych lub współodczuwanych aspektów), które mogą być modyfikowane przez użycie nowych technologii (np. kontaktu on line) - jako elementów wzbogacających fizyczne zaangażowanie etnografa w materialność oraz sensoryczność towarzyszącą badanym w życiu codziennym. Zastosowanie zasad etnografii wielozmysłowej wymaga od badacza jak największej samoświadomości oraz refleksyjnego uwzględniania zmysłowości własnej i otoczenia podczas procesów planowania badania, przeprowadzania wywiadów, pracy terenowej, analizy oraz procesów upowszechniania wyników (Pink 2009, s. 10).

Propozycja autoetnografii wielozmysłowej opiera się zatem na trzech założeniach.

Po pierwsze, co stanowi o istocie opisywanej metody, refleksji oraz analizie poddawane są jednostkowe, osobiste doświadczenia badacza - czynione jest to $z$ uwzględnieniem cielesności oraz zmysłowości. Przy wykorzystywaniu autoetnografii jako metody badania doświadczanych zmysłowowo mikropraktyk życia codziennego ważna jest autorefleksyjność badacza, jego usytuowanie społeczne, a szczególnego znaczenia nabierają również jego ciało, jako „narzędzie”, którym posługuje się $\mathrm{w}$ procesie badawczym, oraz umiejętność rozumienia procesów zachodzących we własnym organizmie. Nie ma możliwości, by oddzielić 
życie od ciała, bo ludzkie doświadczanie rzeczywistości jest zapośredniczone cieleśnie (Jakubowska 2012, s. 13-14). „W procesie poznawczym ciało stanowi dla umysłu niezbędne zaplecze sensoryczne, umożliwiające odbieranie informacji i ich przetwarzanie oraz narzędzie pozwalające na wchodzenie w interakcje z poznawanymi obiektami” - zauważa Anna Kacperczyk (2012, s. 35). Niezależnie więc od tego, co stanowi przedmiot badania i w jaki sposób chcemy go zbadać, jest on nam dostępny dzięki własnym możliwościom sensorycznym (Kacperczyk 2012, s. 26-37). Sposób percepcji rzeczywistości z perspektywy badacza jest więc uwarunkowany podobnie jak sposób percepcji każdego innego aktora społecznego w życiu codziennym. Socjologiczne analizy ciała i cielesności skupiają się przede wszystkim na tych grupach czy kategoriach społecznych, dla których ich ciała stanowią istotny element funkcjonowania w rzeczywistości społecznej (Jakubowska 2012, s. 13-14), jak sportowcy i trenerzy (Wacquant 2004; Kacperczyk 2012, 2016; Jakubowska 2014, 2017) czy tancerze (Byczkowska 2012), a także osoby chore lub z zaburzeniami motorycznymi (Jakubowska 2012). Doświadczanie i świadomość własnego ciała wśród takich grup są bardziej rozwinięte. Ograniczenia ruchu ciała czy siły mięśni stanowią bodziec uświadamiający zakres możliwości organizmu, pozwalają lepiej zrozumieć możliwe reakcje na określone bodźce. Autoetnografia wielozmysłowa praktykowana przez badacza, który nie zna swojego ciała w takim stopniu jak sportowiec czy tancerz (nawet jeśli jest to socjolog zajmujący się ciałem czy cielesnością), może ujawnić istotne niedostatki proponowanej metody. Uważam jednak, że kompetencje badawcze uwrażliwiają nas na doświadczenia w życiu codziennym. Dzięki wyobraźni socjologicznej, a także specyficznej wrażliwości badawczej, jesteśmy w stanie dotrzeć do ukrytych sensów oraz, wydawałoby się, nieurefleksyjnionych znaczeń i praktyk. Ponadto wytyczenie jasnego celu badawczego sprawia, że zarówno wrażliwość na wszelkie doświadczenia, jak i świadomość ciała stają się większe, a każdy bodziec jest bardziej urefleksyjniany. Dzięki temu więcej uwagi poświęcamy na codzienne ucieleśnione doznania, które zazwyczaj są banalizowne, a codzienne automatyzmy stają się przedmiotem pogłębionej refleksji.

Na przykładzie własnych badań mogę stwierdzić, że autorefleksja dotycząca doświadczeń zmysłowych sprawia, że badacz ma większą świadomość własnego ciała doświadczającego bodźców w każdej sferze życia ${ }^{1}$. Uwagę zwraca się

${ }^{1} \mathrm{~W}$ swoich badaniach skupiłem się głównie na analizie doświadczeń zmysłowych towarzyszących życiu codziennemu. Celem prowadzonej autoetnografii było przygotowanie dyspozycji wykorzystanych na dalszych etapach badań. Zamierzałem uwrażliwić samego siebie na zmysłowe aspekty doświadczeń codziennych, a przede wszystkim — przygotować się na problemy, z którymi spotkają się moi badani poproszeni o prowadzenie dzienniczków zmysłowych (forma narracji biograficznych o zróżnicowanej formie zapisów, związanych z doświadczeniami zmysłowymi w ich życiu codziennym). To rozeznanie badawcze odbyło się w lutym i marcu oraz sierpniu i wrześniu 2017 roku. Opierało się ono na prowadzeniu dzienniczka zmysłowego (w skład którego wchodziły zapiski tekstowe, cyfrowe i tradycyjne, zdjęcia, pliki wideo oraz audio) i było pogłębione za 
na reakcje biologiczne organizmu, a także te „przepracowane” kulturowo (np. ostrożne podejście do dotykania poręczy w komunikacji miejskiej ze względu na liczne uwagi/ostrzeżenia przed chorobami i bakteriami przenoszonymi tą drogą). To szczególne zwrócenie uwagi na ciało oraz to, w jaki sposób zmysłowo doświadcza ono rzeczywistości w życiu codziennym, pozwala urefleksyjnić dwie sprzeczne tendencje. Utarty podział na pięć zmysłów formatuje myślenie o odczuwaniu - strukturyzuje opis doświadczeń, a jednocześnie pozwala zwrócić uwagę na wielozmysłowość danego doświadczenia. Zdecydowanie trudno bowiem odseparować zmysły, na przykład doświadczenie jedzenia wiąże się ze smakiem i zapachem, ale również strukturą tego jedzenia (twarde, miękkie, galaretowate), tym, co słychać (chrupie, chlapie, chrzęści) i co widać (potrawy esetyczne, zachęcające do jedzenia, odpychające). Podział na pięć zmysłów okazuje się zatem nieco sztuczny, choć użyteczny podczas budowania teorii czy formułowania opisu.

Po drugie, podstawowym warunkiem intersubiektywizacji doświadczeń zmysłowych stają się umiejętności komunikacji interpersonalnej. Badacz musi posługiwać się rozbudowanym językiem, aby potrafił przekazywać zarówno własne odczucia, jak i odczucia informatorów, musi też posiadać umiejętność budowania metafor czy „językowej wizualizacji” (chodzi o taki język, który dociera do drugiej osoby jako „obraz”, lekki w przyswojeniu i wzbudzający podobne odczucia). Jako badacze powinniśmy być wyposażeni w taki zasób językowy, który zdecydowanie pomaga $\mathrm{w}$ artykułowaniu doświadczeń. Ich intersubiektywizacja na poziomie językowym pozostaje bowiem najważniejszym elementem komunikacji własnych odczuć i doświadczeń (stanowi główny kanał przekazywania tego, czego się doświadcza), jednak w sytuacjach szczególnych, gdy brakuje słów, pomocne stają się inne kanały komunikacji, na przykład wzrokowy (pokazywanie) czy haptyczny (dotykanie). W prowadzonych przeze mnie badaniach używałem swojego rodzaju „translacji” między doświadczeniami różnych zmysłów, opartej na „pozornej nieadekwatności”, czyli przypisywaniu jednemu doświadczeniu określeń językowych charakterystycznych dla innej jego formy (np. „szorstki w smaku”, „brzmi gorzko”). Ważnym elementem opisywanego procesu jest uwzględnienie ,ja” badacza na poziomie tekstu.

Po trzecie, autoetnografia wielozmysłowa zakłada uchwycenie możliwie najpełniejszego obrazu praktyk i doświadczeń zmysłowych, zarówno jeśli chodzi o punkt widzenia (czy szerzej: wielozmysłową optykę), z którego są one analizowane i opisywane, jak i proces docierania do nich. Autorefleksja oraz autonarracja ufundowane na własnych doświadczeniach dnia codziennego (niekoniecznie skrajnych, silnych czy traumatycznych charakterystycznych dla autoetnografii ewokatywnej) zostają skonfrontowane $z$ informacjami pochodzą-

pomocą wywiadów spontanicznych z osobami z różnych środowisk, a także grup nieformalnych, z którymi współpracuję lub do których należę. Główne wnioski posłużyły do stworzenia propozycji autoetnografii wielozmysłowej, którą tu przedstawiam. 
cymi od innych uczestników życia społecznego, dzięki czemu opisywany obraz wydaje się pełniejszy. Własną sytuację i doświadczenia można, moim zdaniem, nie tylko przedstawić odbiorcom $w$ różnej formie (esej, performance, nagranie wideo), ale również odnieść do szerszych kontekstów społeczno-kulturowych, zaznaczając jednak punkt widzenia oraz usytuowanie społeczne przedstawiającego. Jak zauważa Radosław Kossakowski (2014, s. 106): „Doświadczenia autoetnograficzne musiały być referencyjne, by stały się zrozumiałe dla innych. Musiały być ubrane w słowa języka znanego innym, a więc odnosić się do kultury". Oznacza to, że uwzględnienie zarazem optyki innych aktorów społecznych oraz własnego punktu widzenia pozwala na dotarcie do odbiorców w sposób zrozumiały oraz zgodny z ich kodami znaczeniowymi. Jednocześnie budując uogólnienia czy teorie na podstawie osobistych doświadczeń nie zakładamy, że powstaną one $\mathrm{w}$ ostatecznym, nienegocjowalnym kształcie. Wręcz przeciwnie - powstająca teoria staje się przedmiotem negocjacji, otwartą na głosy z zewnątrz formą, zmierzającą dzięki nim do uzyskania pełnego kształtu i treści. Główną zaletą takiego sposobu prowadzenia badań oraz odnoszenia ich wyników do szerszych kontekstów jest zatem teoretyczna otwartość.

Autoetnografia stwarza możliwość zdiagnozowania oraz analizowania obowiązujących dyskursów, a także rozróżnienia tego, jak są one przyswajane przez aktorów społecznych i reprodukowane w odniesieniu do struktur społecznych, w których są oni ulokowani. Również badacz znajduje dzięki temu własne usytuowanie (Kossakowski 2014, s. 110), co pozwala na głębsze zrozumienie narracji innych. Jego zadaniem jest więc nie tylko zawężenie pola do biograficznych doświadczeń, ale umiejscowienie ich w szerszym kontekście społeczno-kulturowym oraz szukanie połączeń z ogólniejszymi teoriami. Innymi słowy, jest to nie tylko forma refleksyjnej autonarracji, ale również system abstrakcyjnych wyjaśnień (Anderson 2014, s. 149; Kossakowski 2014, s. 102). Postulowane podejście polega przy tym na wykorzystaniu zróżnicowanego zestawu technik, dzięki którym możliwe jest dotarcie do poziomu zmysłowości doświadczeń. Autoetnografia wielozmysłowa jest więc $z$ założenia pewnym ogólnym, rozwijającym się polem badań, a nie jasno wyznaczonym zestawem możliwości. Dobór technik oraz narzędzi powinien uwzględniać przede wszystkim kontekst badań, a także specyfikę jego przedmiotu. Mogą to być techniki tradycyjne, jak obserwacja uczestnicząca, wywiad pogłębiony lub swobodny, a także ich twórcze uzupełnienia czy rozwinięcia. Otwiera się tu pole do zastosowania technik wizualnych, audiowizualnych czy kontaktu on line (Pink 2009, s. 10). Nie bez znaczenia pozostają zatem możliwości i kompetencje technologiczne. Prowadzenie notatek terenowych czy też bardziej złożonych form zapisu jest prostsze przy użyciu nowych technologii (np. smartfona $z$ dostępem do sieci), zwłaszcza w sytuacjach codziennych, kiedy wyjęcie kartki i ołówka może być utrudnione. Taka autoetnografia dostarcza wielu danych wizualnych lub audiowizualnych zapisów określonych sytuacji, plików dźwiękowych, a także notatek terenowych i innych form rejestracji. Jednocześnie, tak jak w przypadku moich badań, 
możliwe staje się budowanie hiperłączy lub innych powiązań między konkretnymi obserwacjami, a także wzbogacanie notatek o skojarzenia lub odniesienia $\mathrm{w}$ formie audio oraz wideo.

Zaproponowana tu metoda badawcza, którą określiłem mianem autoetnografii wielozmysłowej, stanowi jedną z wielu dróg umożliwiających badaczowi dotarcie do poziomu mikropraktyk. Pozwala mu całościowo go badać, poznając tym samym charakterystykę codziennych praktyk, znaczenia im przypisywane oraz motywacje ludzkie. Jednocześnie bardzo dobrze wpisuje się w nurt socjologii codzienności, ponieważ (co stanowi istotną zaletę) jako podejście całościowe korzysta $z$ wielu różnych technik pozyskiwania danych (np. wywiadu swobodnego, obserwacji uczestniczącej), co umożliwia uzupełnienie braków jednych możliwościami drugich. Trzeba jednak zachować szczególną ostrożność przy próbach generalizacji analiz czy odnoszenia wyników do szerszego kontekstu społeczno-kulturowego - badacz bowiem, jak każdy inny uczestnik życia społecznego, uwikłany jest w specyficzny splot praktyk towarzyszących jego życiu codziennemu. Zaznaczenie kontekstu społecznego oraz optyki badacza jest zatem niezmiernie ważnym warunkiem rzetelności i wiarygodności analiz.

\section{BIBLIOGRAFIA}

Anderson Leon, 2014 [2006], Autoetnografia analityczna, tłum. Maja Brzozowska-Brywczyńska, „Przegląd Socjologii Jakościowej”, t. 10, nr 3, s. 144-166.

Bendiner-Viani Gabrielle, 2011, Spacerowanie, emocje i zamieszkiwanie. Wycieczki z przewodnikiem po Prospect Heights w Brooklynie, tłum. Waldemar Rapior, w: Maciej Frąckowiak, Krzysztof Olechnicki (red.), Marek Krajewski (współpr.), Badania wizualne w działaniu. Antologia tekstów, Fundacja Nowej Kultury Bęc Zmiana, Warszawa.

Bielecka-Prus Joanna, 2014, Po co nam autoetnografia? Krytyczna analiza autoetnografi jako metody badawczej, „Przegląd Socjologii Jakościowej”, t. 10, nr 3, s. 76-95.

Bogunia-Borowska Małgorzata (red.), 2009a, Barwy codzienności. Analiza socjologiczna, Scholar, Warszawa.

Bogunia Borowska Małgorzata, 2009b, Codzienność $i$ społeczne konteksty życia codziennego, w: Małgorzata Bogunia Borowska (red.), Barwy codzienności. Analiza socjologiczna, Scholar, Warszawa.

Byczkowska Dominika, 2012, „Ciało to mój największy nauczyciel”. Interakcje z własnym ciałem w pracy tancerza, „Przegląd Socjologii Jakościowej”, t. 8, nr 2, s. 212-227.

Denzin Norman K., 2006, Analytic Autoethnography, or Déjà Vu All Over Again, „Journal of Contemporary Ethnography", t. 35, s. 419-428.

Drozdowski Rafał, 2012, Socjologia codzienności, czyli jak przestać „być modna”?, „Kultura i Społeczeństwo", nr 1.

Dziamski Grzegorz, 2001, Zwrot postmodernistyczny albo powrót wielkich teorii w naukach spotecznych, „ER(R)GO. Teoria - Literatura - Kultura”, nr 1 (2), s. 43-48.

Ellis Carolyn, 1995, Final Negotiations: A Story of Love, Loss, and Chronic Illness, Temple University Press, Philadelphia. 
Ellis Carolyn, 2004, The Ethnographic I: A Methodological Novel about Autoethnography, AltaMira Press, Walnut Creek, CA.

Ellis Carolyn, 2009, Revision: Autoethnographic Reflections on Life and Work, Left Coast Press, Walnut Creek, CA.

Ellis Carolyn, Bochner Arthur P., 2000, Autoethnography, Personal Narrative, Reflexivity, w: Norman K. Denzin, Yvonna S. Lincoln (red.), Handbook of Qualitative Research, Sage, Thousand Oaks.

Giddens Anthony, 2007, New Rules of Sociological Method: A Positive Critique of Interpretative Sociology, Polity Press, Cambridge.

Grzeszczyk Ewa, 2009, Jak pochwycić rozmówcę w sieci, czyli wywiady przeprowadzane przez internet jako technika socjologii jakościowej użyteczna w badaniu życia codziennego, w: Małgorzata Bogunia-Borowska (red.), Barwy codzienności. Analiza socjologiczna, Scholar, Warszawa.

Hałas Elżbieta, 2011, Refleksyjność jako zasada i problem teorii społecznej, „Zagadnienia Naukoznawstwa", t. 47, nr 2, s. 191-202.

Hayano David, 1979, Auto-Ethnography: Paradigms, Problems, and Prospects, „Human Organization”, t. 38 , s. 99-104.

Jakubowska Honorata, 2012, Ciało jako przedmiot badań socjologicznych — dylematy, pominięcia, możliwości, „Przegląd Socjologii Jakościowej”, t. 8, nr 2, s. 12-31.

Jakubowska Honorata, 2014, Gra ciatem. Praktyki i dyskursy różnicowania płci w sporcie, Wydawnictwo Naukowe PWN, Warszawa.

Jakubowska Honorata, 2017, Skill Transmission, Sport and Tacit Knowledge: A Sociological Perspective, Routledge, Oxford-New York.

Kacperczyk Anna, 2012, Badacz $i$ jego ciało $w$ procesie zbierania $i$ analizowania danych - na przykładzie badań nad społecznym światem wspinaczki, „Przegląd Socjologii Jakościowej”, t. 8, nr 2, s. 32-63.

Kacperczyk Anna, 2014, Autoetnografia - technika, metoda, nowy paradygmat? O metodologicznym statusie autoetnografii, „Przegląd Socjologii Jakościowej”, t. 10, nr 3, s. 32-74.

Kacperczyk Anna, 2016, Społeczne światy. Teoria — empiria - metody badań. Na przykładzie świata wspinaczki, Wydawnictwo Uniwersytetu Łódzkiego, Łódź.

Kafar Marcin, 2011, Wprowadzenie, w: Marcin Kafar (red.), Biografie naukowe. Perspektywa transdyscyplinarna, Wydawnictwo Uniwersytetu Łódzkiego, Łódź.

Kossakowski Radosław, 2014, Medytacja i futbolowa gorązka. O potencjale, ograniczeniach i domknięciach autoetnografii, „Przegląd Socjologii Jakościowej”, t. 10, nr 3, s. 96-122.

Kurczewski Jacek, 2009, Pamiętnik życia codziennego. Refleksja nad metoda, w: Małgorzata Bogunia-Borowska (red.), Barwy codzienności. Analiza socjologiczna, Scholar, Warszawa.

Lofland John i in., 2009, Analiza układów społecznych. Przewodnik metodologiczny po badaniach jakościowych, tłum. Anna Kordasiewicz, Sylwia Urbańska, Monika Żychlińska, Scholar, Warszawa.

Maślanka Tomasz, Strzyczkowski Konstanty (red.), 2012, Między rutynq a refleksyjnościa. Praktyki kulturowe i strategie życia codziennego, Wydawnictwo Uniwersytetu Warszawskiego, Warszawa.

Mokrzycki Edmund, 1971, Założenia socjologii humanistycznej, Państwowe Wydawnictwo Naukowe, Warszawa.

Olechnicki Krzysztof, 2009, Badanie fotoblogów jako badanie codzienności, w: Małgorzata Bogunia Borowska (red.), Barwy codzienności. Analiza socjologiczna, Scholar, Warszawa.

Pink Sarah, 2009, Doing Sensory Ethnography, Sage, London-Thousand Oakes.

Reed-Danahay Deborah E. (red.), 1997, Introduction, w: Deborah E. Reed-Danahay, Auto/Ethnography: Rewriting the Self and the Social, Berg, Oxford-New York.

Rogowski Łukasz, Skrobacki Radosław, Mroczkowska Dorota, 2012, Codzienność w kryzysie, „Kultura i Społeczeństwo", nr 1.

Sulima Roch, 2000, Antropologia codzienności, Wydawnictwo Uniwersytetu Jagiellońskiego, Kraków. 
Sztompka Piotr, Bogunia-Borowska Małgorzata (red.), 2008, Socjologia codzienności, Znak, Kraków.

Wacquant Loïc, 2004, Body and Soul: Ethnographic Notebooks of an Apprentice Boxer, Oxford University Press, New York.

Wagner Roy, 2003, Wynalezienie kultury, w: Marian Kempny, Ewa Nowicka (red.), Badanie kultury. Elementy teorii antropologicznej, tłum. Anna Malewska-Szałygin, Wydawnictwo Naukowe PWN, Warszawa.

\title{
SENSORY EXPERIENCE IN EVERYDAY LIFE: MULTISENSORY AUTOETHNOGRAPHY
}

\author{
Przemysław Rura \\ (Adam Mickiewicz University in Poznań)
}

Summary

The author presents a research approach that he defines as multisensory autoethnography. He proposes that it should be used for the study of sensory experiences in everyday life, as an important aspect of micropractices. The article is composed of three parts. In the first, the research context is described in reference to the tradition of the sociology of everyday life. The second part discussed the theoretical and methodological approaches that are the basis for autoethnography in general. The third part contains a description of the method proposed by the author. The three assumptions of the method are (1) the personal experience of the researcher, (2) interpersonal communication abilities, and (3) the attempt to grasp the fullest picture of the practices and sensory experiences of the researcher and the persons studied.

\section{Key words / słowa kluczowe}

autoethnography / autoetnografia, senses / zmysły, everyday life / codzienność, micropractices / mikropraktyki, sensory autoethnography / autoetnografia wielozmysłowa 